\title{
Identification of biodiversity assets on selected Kimberley islands: background and implementation
}

\author{
L.A. Gibson and N.L. McKenzie \\ Department of Environment and Conservation, Science Division, \\ PO Box 51, Wanneroo, Western Australia 6946, Australia. \\ Email: Lesley.Gibson@dec.wa.gov.au
}

\begin{abstract}
The Northern Kimberley biogeographic region has been identified as one of Australia's biodiversity hotspots. Although susceptible to many processes threatening biodiversity in adjacent regions, the Northern Kimberley has experienced no known plant or animal extinctions to date. Of particular conservation value are the extensive archipelagos and island groups along its drowned coastline. Collectively, these islands form a microcosm of substrates and vegetation communities widespread on the adjacent mainland, so they are likely to be important refuges for fauna, particularly as they have been largely sheltered from mainland disturbances. In December 2006, a 3-year biodiversity survey of 24 of the islands commenced. The survey was designed to provide the knowledge base to underpin future management actions to protect the biodiversity values of the islands. This survey focused on the species groups believed to be most at risk from threatening processes affecting biodiversity on the mainland. It included mammals, reptiles, frogs, land snails, plants and birds. Here, we describe the background, rationale, objectives and implementation of this survey, including general descriptions of the islands sampled.
\end{abstract}

KEYWORDS: biological survey, conservation status, island conservation, survey logistics

\section{BACKGROUND}

The vast and remote wilderness of the Kimberley region of northern Western Australia supports a rich diversity of plant and animal species, many of which are endemic to the region, justifying its status as a National Biodiversity Hotspot (http:// www.environment.gov.au/biodiversity/hotspots/ national-hotspots.htm). In general, the tropical north of Australia has been viewed as a biological stronghold, resilient to many human-associated disturbances (Fitzsimmons et al. 2010; Woinarski et al. 2010). However, there is growing evidence to suggest otherwise, particularly with regard to the mammal species, with numerous contractions in distribution observed (Fitzsimmons et al. 2010; Woinarski et al. 2010, 2011). The Kimberley region is no exception; changes in land use and practices over the last century have coincided with a wave of local extirpations among mediumsized mammals, and reductions in the abundance of some small mammal and bird species (Start et al. 2007; Burbidge et al. 2008; Legge et al. 2011). The expanding pastoral industry and changed fire regimes, until recently characterised by late dry season extensive and intense fires, have been responsible for the most overt changes in Kimberley landscapes (McKenzie et al. 1991; DEC 2009). Exotic weeds, feral cats, donkeys, horses, cattle and pigs have also contributed to loss of biodiversity in the Kimberley (May and McKenzie 2002; Carwardine et al. 2011). The most recent threat is the arrival of the Cane Toad (Rhinella marina) into the region, which is likely to add further pressure to already modified and vulnerable ecosystems (How et al. 2009).

The impacts of these threatening processes have not been uniform across the Kimberley. The high rainfall, near-coastal region of the northwest Kimberley has experienced no known extinctions to date (McKenzie et al. 2007). Several mammal species with formerly wider distributions have now contracted to this area including three of the Kimberley's four endemic species (Burbidge et al. 2008). Limited access to this extremely rugged and remote area has largely restricted comprehensive assessments of its biodiversity, and it is only in recent years that the compositional complexity of its flora and vertebrate fauna has been fully appreciated (DEC 2009). The low-nutrient soils of the northwest have largely discouraged pastoral activity in this area, but there is now clear evidence 
of localised habitats such as rainforest and riverine vegetation being degraded, along with a landscapescale simplification of the savanna ecosystems that dominate the region (DEC 2009). Damage to rainforest patches by fire and cattle, in combination, was noted as early as 1976 (McKenzie et al. 1991). As a high proportion of the region's terrestrial biodiversity occurs within these patches, any detrimental processes effecting the rainforests has dire consequences for maintaining the region's biodiversity (McKenzie et al. 1991; Russell-Smith et al. 1992). Rainforests (sometimes referred to as vine thickets) are particularly significant for the many endemic invertebrate species they harbour such as the strongly localised camaenid land snails and earthworms (e.g. Solem 1991). Other introduced species have also been progressively infiltrating the northern Kimberley, for example wild passionfruit (Passiflora foetida) (CCWA 2010; Carwardine et al. 2011).

Given the escalating threatening processes on the Kimberley mainland, the extensive coastal archipelagos and island groups located along the northern Kimberley coast potentially offer important conservation security for Kimberley biodiversity. Formed by rising sea levels, the more than 2,500 islands are thought to have last been part of the mainland as recently as 8,000 to 10,000 years ago, although a few islands may have had a more recent separation (Nix and Kalma 1972; Burbidge and McKenzie 1978). Because the islands have been naturally sheltered from many mainland disturbances, they collectively support near pristine representative examples of much of the adjacent mainland's geological surfaces and vegetation communities (May and McKenzie 2002). As such, they are likely to be important refuges for fauna, including species that have restricted and/or contracting mainland distributions. Many islands are also important breeding sites for seabirds and turtles (CCWA 2010).

In the last decade or so, the coastal region of the Kimberley has increasingly been exposed to disturbances associated with the influx of casual visitors, tourism, fishing, aquaculture, mining, and oil and gas exploration (Carwardine et al. 2011). While these industries offer potential economic benefits, they also can place increasing pressure on the health of the islands' biodiversity if not properly regulated and managed to mitigate or minimise impacts. Of particular concern is the increased risk of exotic species being introduced to the islands by visitors (Nias et al. 2010). A further potential concern is the growing interest in the islands for natural resource extraction. Currently, many of the islands have been effectively unmanaged for conservation, making them vulnerable to unmitigated exploitation. Offshore islands have been identified as one of 10 Australian ecosystems most vulnerable to tipping points, in which modest environmental changes can lead to disproportionately large changes in ecosystem properties (Laurance et al. 2011). Islands are particularly vulnerable to environmental changes due to their restricted size, physical isolation, narrow environmental envelope, reduced species compositional complexity and susceptibility to species invasions (Burbidge and Manly 2002; Laurance et al. 2011).

The islands are not only important for their biodiversity values, but also for their cultural and traditional values. A number of islands are reserves for 'Use and Benefit of Aborigines' which are vested in the Aboriginal Lands Trust. Aboriginal people maintain strong connection to the region and the islands have been the subject of native title determinations or are under native title claim. Therefore, the survey of the islands involved close liaison with the appropriate Traditional Owners. The survey provided both an opportunity to build on the knowledge of plants and animals held by Traditional Owners as well as training opportunities for Traditional Owners who are interested in complementing their knowledge base for future management. Such a partnership is timely as Aboriginal people also have management responsibilities for the islands through native title, Aboriginal reserve tenure, proposed Commonwealth Indigenous Protected Areas and are developing ranger programs.

There is an urgent need to formulate policy and management strategies that address conservation, recreation and sustainable development of the islands to ensure that their biodiversity and cultural values are protected (CCWA 2010). The general lack of knowledge of the terrestrial biodiversity on a large majority of Kimberley islands highlighted the need to conduct a systematic biological survey of the islands off the Northern Kimberley coast to inform management planning.

\section{RATIONALE}

It was noted in the Biodiversity Audit of Western Australia (May and McKenzie 2002) that the extensive Kimberley coastal archipelagos present an opportunity to protect intact ecosystems that have not been affected by various threatening processes on the mainland, and that these islands support populations of many endemic and/or threatened species requiring special attention on the mainland. Two high priorities for biodiversity conservation research include the need to (1) identify, characterise and record the distribution and habitat of native species that may 


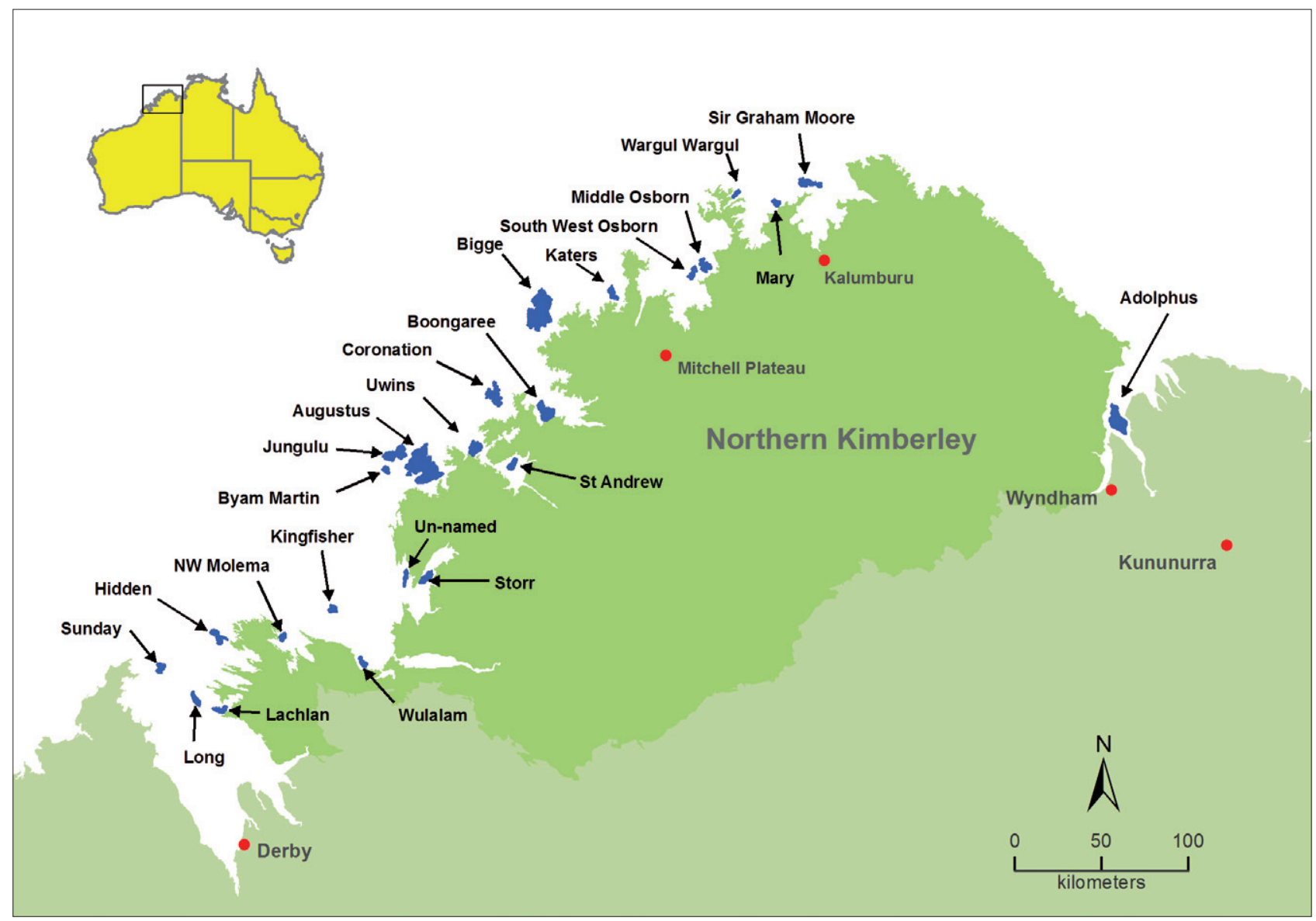

FIGURE 1

Location of Kimberley islands selected for a survey of their biodiversity assets along the north-west coast of Australia.

be threatened, and (2) determine the conservation status of native species (ANZECC 2001). A biodiversity survey of the Kimberley islands would provide data to address these priorities.

In response to the likely arrival of the Cane Toad into Western Australia, the State launched a Cane Toad Initiative in December 2004. A strategy in that initiative involved identifying key assets at risk from Cane Toads in Western Australia and protecting these ahead of any Cane Toad invasion. A Kimberley island survey would contribute to the initiative by increasing our knowledge of relevant biodiversity assets occurring on the islands that are in the immediate path of Cane Toads on the mainland, and suggesting options for protecting and managing many of these assets into the future.

\section{OBJECTIVES}

In December 2006, the Western Australian Department of Environment and Conservation (DEC), in collaboration with the Kimberley Land Council (KLC), Western Australian Museum (WAM) and Australian Museum, started preparations for a biological survey of the Northern Kimberley islands. The project was jointly funded by the Western Australian and Australian governments, with three dry season (winter) and wet season (summer) surveys planned over three years.

Specific objectives were to:

- Build on existing knowledge of targeted components of biodiversity and determine the conservation status of islands off the Northern Kimberley coast.

- Identify locations of species susceptible to mainland threats, including Cane Toads, and identify the potential of islands as natural refuges.

- Provide baseline information for future ecological survey and monitoring.

- Provide the knowledge base to underpin decisions involving conservation and development, including nature-based tourism, non-renewable resource extraction and infrastructure development. 
을을

变两。

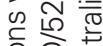

흐응

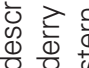

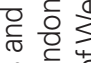

学家

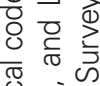

응

능

(1)

त्व 0

은

完亭

ㄴํㅇ

䨌 등 음

范

过 0

두에

(1) D

잉

은 등

की

त ब

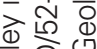

离

है

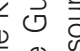

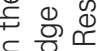

은 읗

है एँ

ट

更 $\overline{\mathrm{N}}^{-4}$

苋宁

तु कि ग

응

ป ㅇํㅇ 응

(1)

융 융

ธั

范等

D) क्ष

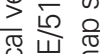

뜰

$\sum^{2} \overline{0}$

त ह ह

ह $\stackrel{\otimes}{\risingdotseq}$

등 응

岃

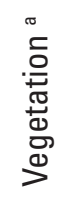

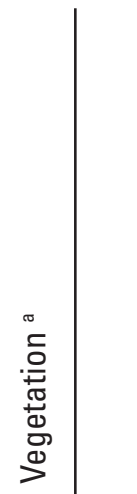

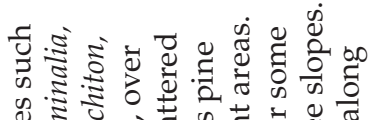

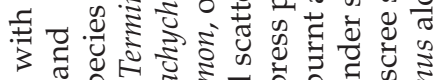

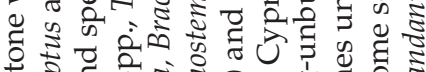

क्षे

记

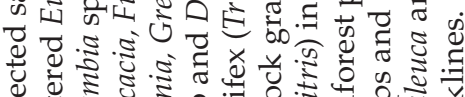

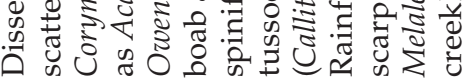

틈

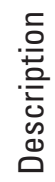

石

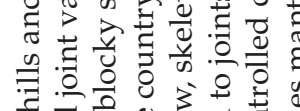

골

离

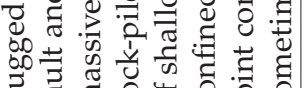

$\overrightarrow{2}$

ฮั

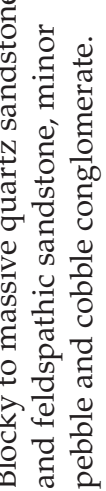

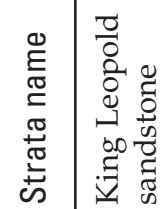

$\begin{array}{ll}\frac{0}{0} \\ \frac{0}{0} \\ \frac{0}{0} \\ \frac{0}{0} \\ \frac{0}{0} & \frac{7}{1}\end{array}$

0
0
0
0
0
0
0
0
0
0
0
3
3

$\frac{3}{2}$
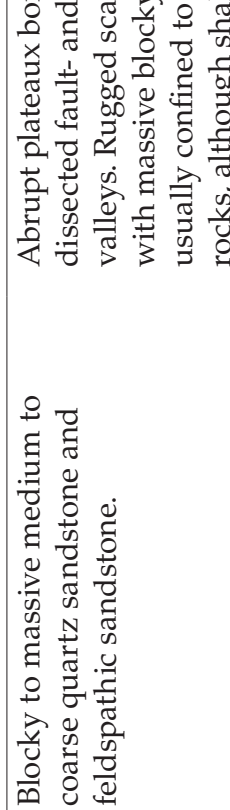

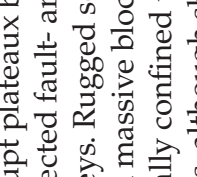

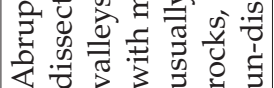

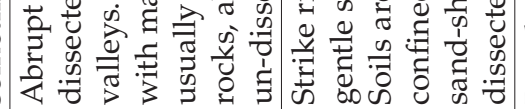

굴

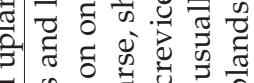

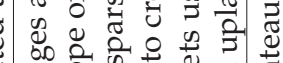

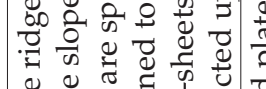

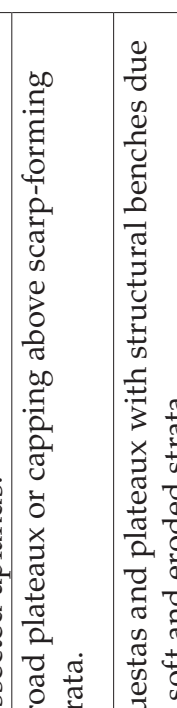

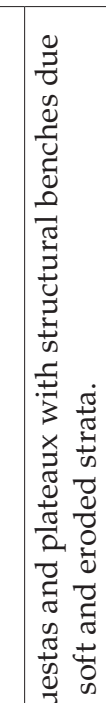

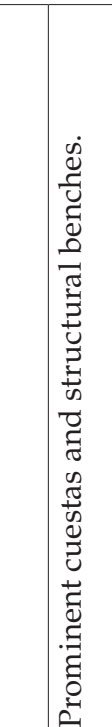

.

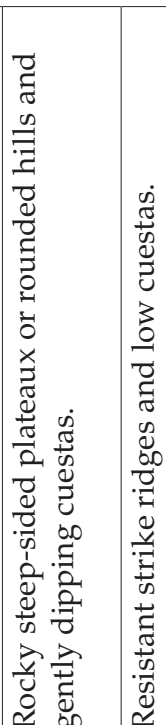
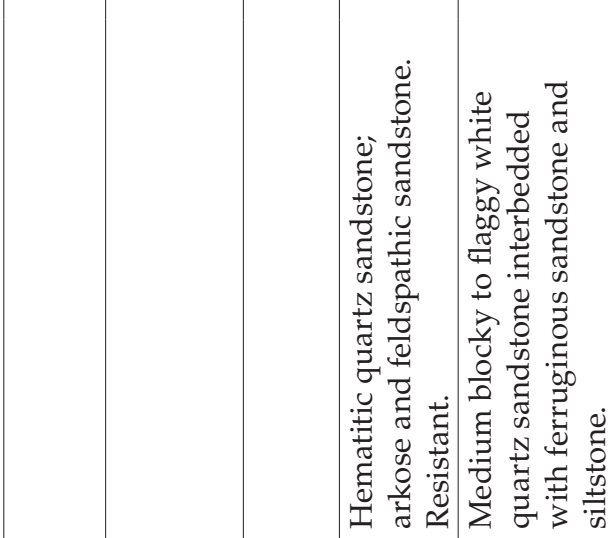

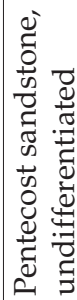

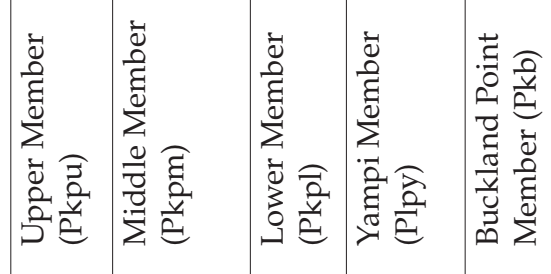

$\frac{2}{2}$ 


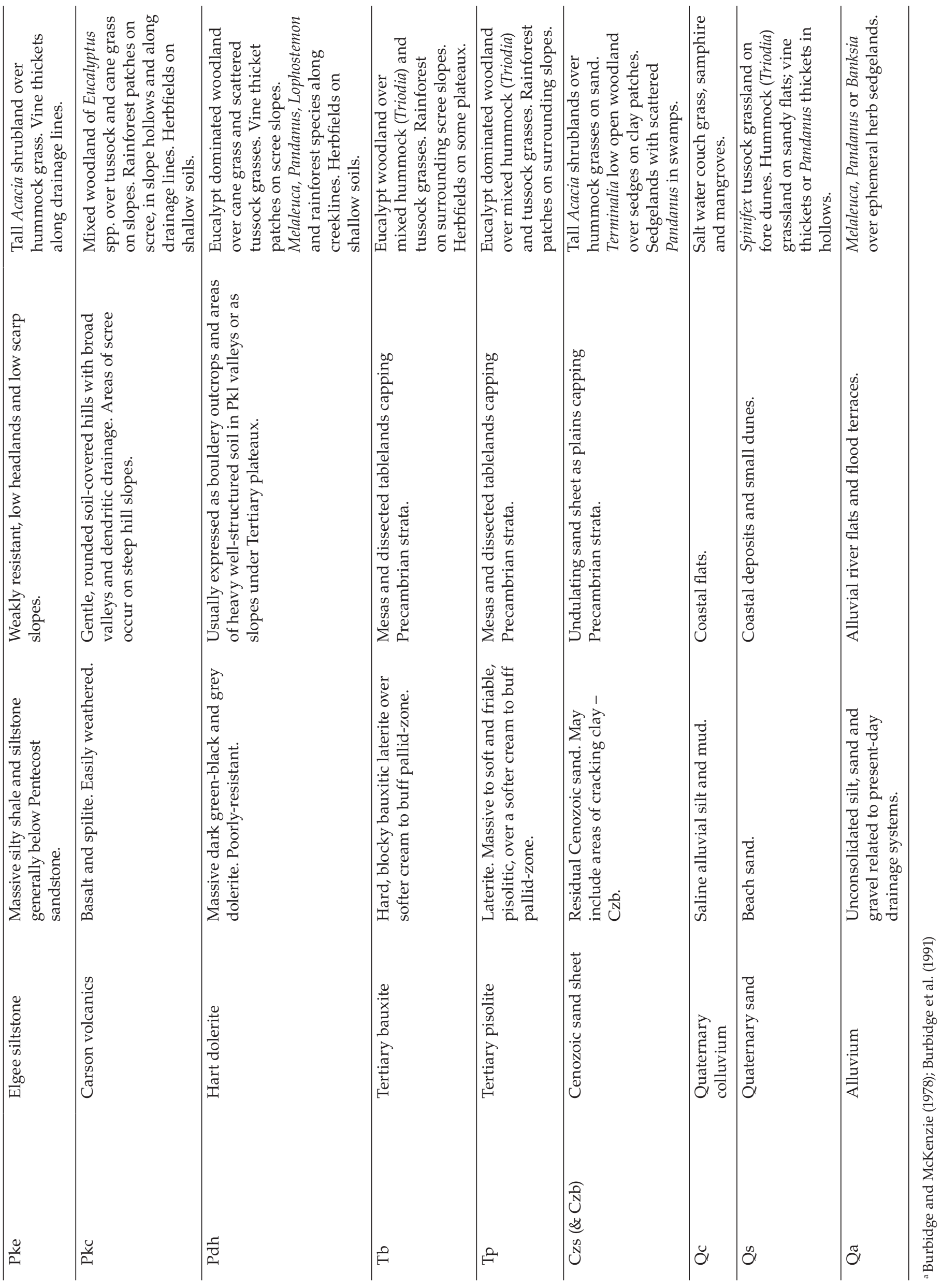




\section{STUDY AREA}

The islands off the Northern Kimberley coast extend from King Sound, near Derby, in the southwest to Cambridge Gulf in the northeast (approximately $800 \mathrm{~km}$, Figure 1). They are grouped into a number of loose associations, including the large Buccaneer and Bonaparte Archipelagos.

The Kimberley experiences a tropical monsoon climate with two distinct seasons. A dry season extending from around April to October, and a wet season from November to March when almost all rainfall occurs. Average yearly rainfall ranges from $>1,500 \mathrm{~mm}$ in the sub-humid north-west to $<800$ $\mathrm{mm}$ in the south (http://www.bom.gov.au). Tropical cyclones and monsoonal cells produce much of the coastal rainfall, with heavy falls occurring over short periods. Temperatures are mild to hot throughout the year, averaging between $25^{\circ} \mathrm{C}$ and $35^{\circ} \mathrm{C}$, with a high relative humidity peaking during the wet season.

As a flooded coastline, the geomorphology of the islands resembles that of the adjacent mainland, although even the largest islands generally include only two or three of the Precambrian rock types present on the mainland (see Burbidge and McKenzie 1978; Burbidge et al. 1991). The geomorphology of the islands is determined by these sandstone or volcanic strata (Table 1). Briefly, the three main sandstone strata (Warton, King Leopold and the less rugged Pentecost) are expressed as resistant, cliff-forming quartz sandstones, resulting in a rugged, dissected terrain. The Carson volcanics are expressed as rounded, usually soil covered, undulating country with gentle gradients and dendritic drainage. Hart dolerite occurs as dark grey to black bouldery outcrops in King Leopold sandstone valleys, or as slopes under Tertiary laterite mesas and dissected tablelands capping the Precambrian strata on some of the more northerly islands. Cenozoic deposits of sandy-textured soils mantle sandstone and volcanic surfaces on some islands. The shorelines of the islands are predominantly rocky, although Quaternary soils often occur as extensive littoral flats with grey saline mud in sheltered bays and in narrow stretches along shorelines, while sandy beaches are present in embayments between rocky headlands on some islands.

Broad vegetation communities on the islands include tropical savanna, hummock grassland, rainforest, coastal tussock grassland, riparian paperbark and Pandanus woodlands, and mangroves (Table 1). More detailed vegetation descriptions for some islands are given in Burbidge and McKenzie (1978) and Burbidge et al. (1991).
The islands have been afforded some protection from an altered fire regime, owing to an increase in the frequency, intensity and scale of fires that have occurred on the mainland in more recent times. Fire tends to occur sporadically on the islands largely as a result of lightning strikes, although fire was employed by Aboriginal people on some of the islands in the past. A paucity of fire on the islands potentially provides refuge for species vulnerable to fire, including the landscape consequences of frequent hot fires late in the dry season. In a remote area such as the Kimberley, compiling a history of fire occurrence is not straight forward. Since 1993, fire scars have been routinely identified and recorded from satellite imagery. However, technological limitations, such as identifying small or low intensity fires and masking by cloud and other atmospheric conditions, has resulted in an incomplete record. We do know that extensive fires have occurred on the two largest islands in the last five years (Augustus and Bigge Islands; DEC 2009).

\section{ISLAND SELECTION}

Of the approximately 2,633 islands, 145 are at least 100 ha in size, and only 20 exceed 1,000 ha (CCWA 2010). While even tiny islands can support a diversity of flora and fauna, logistically it was only possible to sample a small subset. Islands were selected to meet two primary criteria:

1. High biodiversity and threatened species. The array of fauna and flora species and community diversity is likely to be greatest on larger islands (Losos and Ricklefs 2010) with a variety of geological and topographical surfaces. Moreover, such islands will have a greater capacity to absorb disturbances such as fire. These islands are therefore likely to be the focus for conservation, and were specifically targeted for survey.

2. Environmental diversity. It is also important that conservation strategies address bio-regional variation, the diversity in factors such as climate, geology, distance from mainland or other islands as well as risks from the various threatening processes (e.g. proximity to larger river mouths; Cane Toads are known to have crossed several kilometres of sea in flood waters to invade islands [Woinarski et al. 2011]). Additional islands were chosen to address bioregional variation.

Based on these criteria, 24 islands were selected, between Sunday Island in the south and Sir Graham Moore Island in the north. Additionally, Adolphus Island in Cambridge Gulf to the east was included (Figure 1). Islands belonging to each group found along the Northern Kimberley coast are represented, including several in the Bonaparte 
and Buccaneer Archipelagos. Although many islands along this coast are only separated from the mainland by a narrow channel, we avoided those connected to the mainland by mangroves, littoral mudflats or reef exposed at low tide as this could lead to immigration from the mainland. Latitude, longitude, area, tenure, geological units and summary descriptions of each island selected for survey are given in Tables 1 and 2.

Although presently uninhabited, signs of Aboriginal visitation are evident on the majority of the islands. A non-denominational Protestant mission was established on Sunday Island in 1899 and was occupied until 1957. There are also remains of an abandoned outstation on Sunday Island. In recent years there has been a dramatic increase in visitation to some of the islands as a result of ship based tourism, other recreational visitors and mining exploration.

\section{SURVEY HISTORY}

Knowledge of the non-marine biodiversity of the Kimberley islands as a whole is limited although some survey work has been undertaken on several of the larger islands. However, there is no biological information on the majority of islands. Earliest published records are from dry season surveys conducted by the Department of Fisheries and Wildlife between 1971 and 1973 (Burbidge and McKenzie 1978). There have been a small number of surveys since then, but only a few have resulted in published accounts (e.g. McKenzie et al. 1991, 1995; Keighery et al. 1995; How et al. 2006; Start et al. 2007). More recently, there have been a number of surveys conducted by environmental consultants for the resource sector, with information only available via specimens lodged with the WAM or Western Australian Herbarium. The biological survey history for the islands we chose to sample is shown in Table 2, but a variety of other more specific collections or observations are available, including land snail specimens collected in 1984 by Vince Kessner, and flora and bird data collected since the 1980s during ecotour and Western Australian Naturalist Club visits led by Kevin Kenneally and Kevin Coate (pers. comm.).

\section{TARGET GROUPS}

Our survey focused on the groups of species most at risk from the threatening processes affecting biodiversity on the Kimberley mainland, including the invasion of the Cane Toad, changed fire regimes and grazing, and therefore most likely to require conservation action. These include mammals, reptiles, frogs, land snails, birds and plants.

- Mammals such as possums, bandicoots, quolls, small wallabies and rodents have suffered significant contractions in distribution in the Kimberley, with remaining populations concentrated in the north-west of the region (Burbidge et al. 2008). Two mammal species endemic to the Kimberley-the tiny monjon rock-wallaby (Petrogale burbidgei) and scaly-tailed possum (Wyulda squamicaudata)—are restricted to the north-west, as is the golden-backed tree rat (Mesembriomys macrurus) which was once more widely distributed in northern Australia (Burbidge et al. 2008). Cane Toads pose an additional threat to some of these mammals, as evidenced by the decline in northern quoll (Dasyurus hallucatus) populations in the Northern Territory (Shine 2010).

- Frogs, varanids, snakes, large skinks and dragons are likely to be particularly vulnerable to toads (Shine 2010). Monitoring in the Northern Territory has shown that populations of the yellow-spotted monitor (Varanus panoptes) have collapsed following the arrival of Cane Toads (Shine 2010). Competition for resources and predation between native frog species and Cane Toads has also been documented (Shine 2010).

- Camaenid land snails have a high degree of local endemism on the Kimberley mainland (Solem and McKenzie 1991) and they were expected to show similar levels of endemism on the islands. Due to their limited mobility, populations of land snails are particularly susceptible to the impacts of fire and other factors that affect their habitat (e.g. Lydeard et al. 2004). Information about the distribution of animals with limited mobility and restricted distributions, such as the land snails, is crucial to gauge the possible impacts of proposed mining or other industrial developments. Additionally, a laboratory trial has shown that Cane Toads readily eat camaenid snails (Pearson et al. 2009).

- Some carnivorous and omnivorous birds such as raptors are potentially threatened by Cane Toads (Shine 2010). Additionally, a number of granivorous birds are declining across northern Australia in part at least due to a change in fire regimes (Carwardine et al. 2011). Records of bird species on the islands will improve overall knowledge of their distributions.

- Frequent burning, erosion and weeds threaten many plant species and communities in the Kimberley (McKenzie et al. 1991; DEC 2009; Carwardine et al. 2011). Site-based vegetation descriptions also form benchmarks for monitoring island environments and understanding future change. 
<smiles>[BH2-]</smiles>

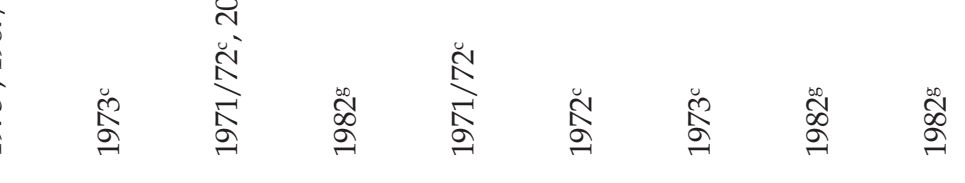

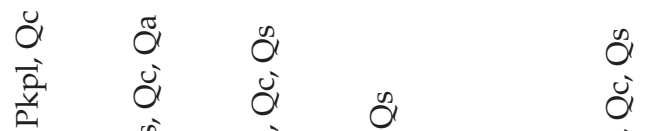

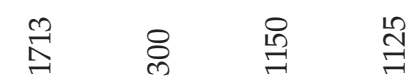

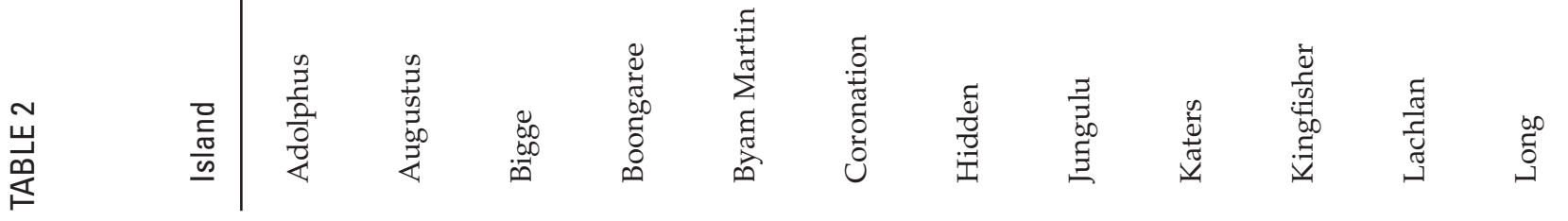




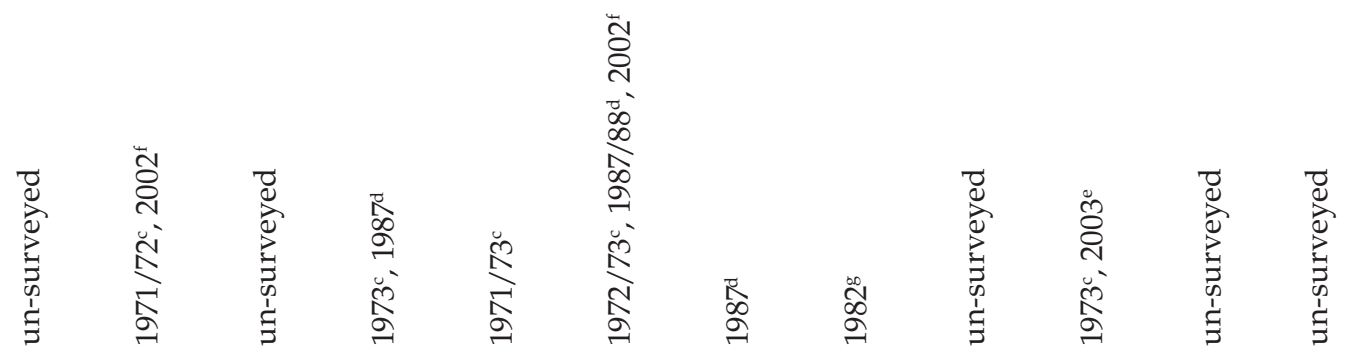

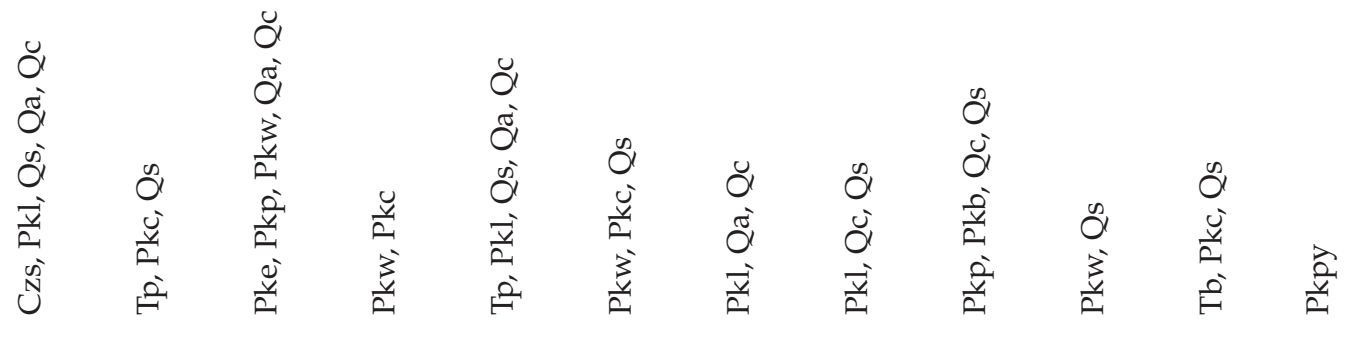

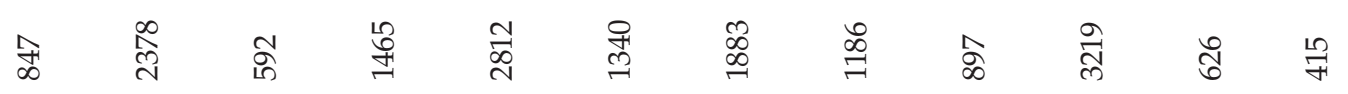

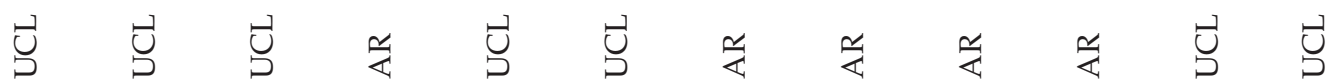

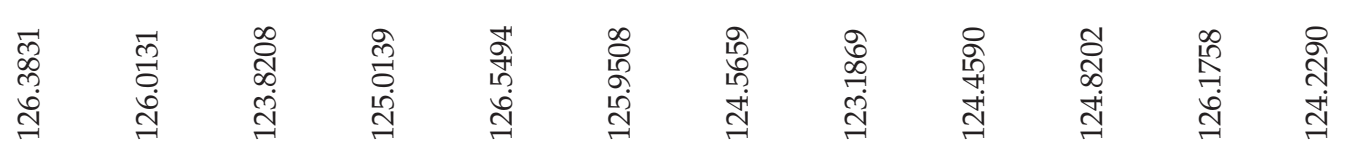

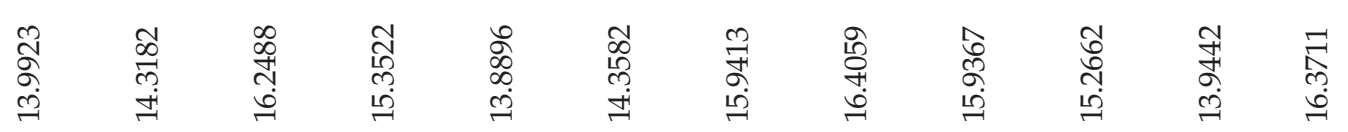

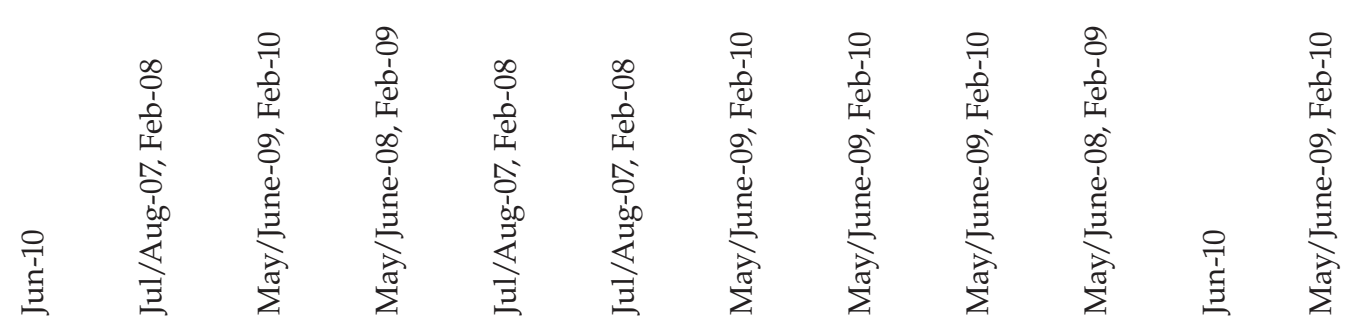

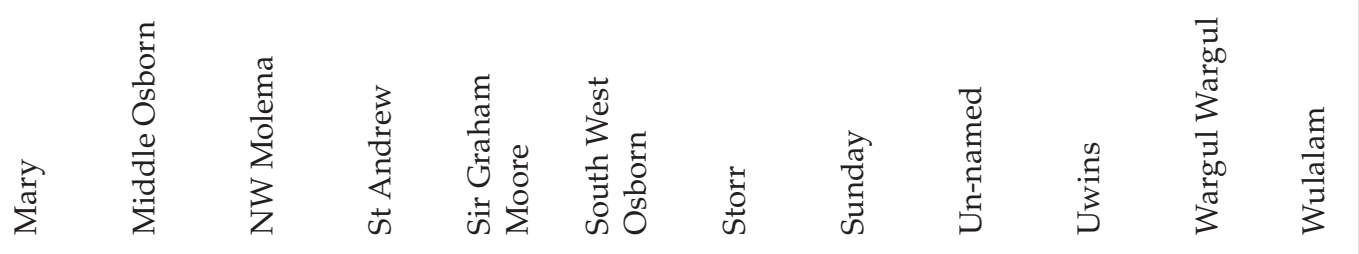

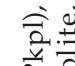

要.

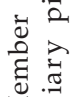

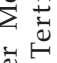

弯 1

产.

$\frac{2}{5}$

焉离

$\frac{\oplus}{\partial}$

过

焉

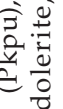

若 菏

$\infty \sum 13$

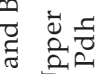

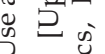

ธ

t)

क्ञ

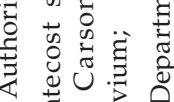

$\infty \quad D_{0} 1$.

表安

尝

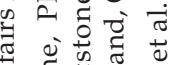

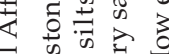

त

:00

至

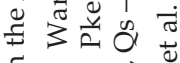

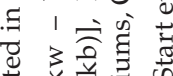

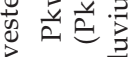

ปे

过

उ.

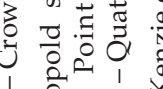

先宁

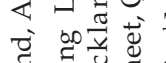

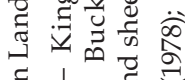

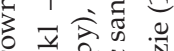

记

क्ष

ฮ व

5.

U 


\section{IMPLEMENTATION}

Survey team base camps were placed within walking distance of as many habitat types as possible. Information on geology and vegetation from maps, satellite imagery and previous experience was used to select a number of potential campsites on each island. To avoid culturally sensitive areas, the sites were presented to the Traditional Owners for their consideration and approval. A reconnaissance flight was then used to confirm the final site(s) on each island. Two sites were needed to encompass the environmental variation of the seven largest islands in our survey: Adolphus, Augustus, Bigge, Coronation, Jungulu, Middle Osborn and Sir Graham Moore.

The islands were sampled over four dry seasons and three wet seasons, from July 2007 to June 2010 (Table 2). Although three dry seasons were originally planned, sufficient funds permitted a further two islands to be sampled during a fourth dry season. To avoid introducing exotic species to the islands, we adhered to a strict biosecurity protocol (Nias et al. 2010). Isolation, rugged topography and limited access in the northern Kimberley make planning field work logistically demanding. Wet and dry season surveys required different strategies due to the prevailing weather conditions.

\section{DRY SEASON (WINTER) SURVEYS}

The dry season surveys each involved three teams; each team comprised two vertebrate zoologists, a land snail specialist, a botanist and usually two Traditional Owners (see Appendix 1). Teams and equipment were transported to, and between, islands in a helicopter (AS350SD Squirrel, Bell B206 Jet Ranger or Bell B407 Long Ranger, depending on availability). Teams were moved to a new campsite every six days, so that each team sampled three sites in one dry season field trip (i.e. nine sites in total over 18 days). Initial placement of teams on the islands was staggered, with the three teams placed at their sites over three consecutive days. Food and water were resupplied by helicopter every three days.

The helicopter schedule was coordinated from a base camp on the mainland (Mitchell Plateau for the first two surveys and Derby for the third survey; see Figure 1). The base camp team also managed communications, food and water supplies, Traditional Owner transfers and any emergencies.

Mammal trap lines were set in the habitats surrounding each campsite. Usually there were four lines per campsite, each comprising alternating medium Elliott traps $(33 \times 10 \times$
$10 \mathrm{~cm})$, large Elliott traps $(50 \times 17 \times 17 \mathrm{~cm})$ and collapsible Tomahawk cage traps $(51 \times 18 \times 18$ $\mathrm{cm}$ ) approximately $10 \mathrm{~m}$ apart. Traps were baited with a mixture of peanut butter and rolled oats, and set for either four or five consecutive nights. These transects were searched during the day and at night (by spotlight), and sightings or signs of presence (i.e. scats and tracks) were also recorded. In addition, hair found in predator scats was identified. On at least two nights at each site, ultrasonic equipment was used to record the echolocation calls of bats for later identification.

Funnel traps were used to sample reptiles; the first time funnel traps have been used on islands. Two lines of eight funnel traps were established in the vicinity of each mammal trap line. These traps were positioned along low aluminium fly-wire fences ( $30 \mathrm{~m}$ in length, $0.2 \mathrm{~m}$ high) to direct animals into the funnels. Opportunistic searching (foraging) for reptiles along trap lines, and in other areas on the island, supplemented the systematic sampling. Spotlighting at night was used to detect nocturnal reptiles such as geckos.

At least one plant quadrat of $50 \times 50 \mathrm{~m}$ was established and sampled in each habitat type, usually on the vertebrate trap line. Dimensions of 'quadrats' in linear habitats such as creek lines were modified to best encompass the habitat. Site descriptors (e.g. landform setting and substrate attributes) were recorded for each quadrat. Soil samples from the top few centimetres of the profile were collected at 10 points across the quadrat and bulked for later chemical analyses.

Land snail species, which aestivate during the dry season, were sampled by raking, digging, lifting rocks and examining tree crevices, mainly in densely vegetated areas such as rainforest patches. Litter samples were also collected and later sorted for snails in the laboratory.

Bird species were recorded opportunistically from sightings and calls.

\section{WET SEASON (SUMMER) SURVEYS}

All sites were re-sampled in the wet season with the exception of Mary and Wargul Wargul islands (due to time restrictions), with a focus on frogs, land snails and plants. As the activity of frogs and land snails increases in the wet season, additional species to those recorded in the dry season were likely to be discovered. Extra plant species were also likely to be found due to the wet season emergence of annuals. Additionally, flowers or fruit of sterile flora collected in the dry season might be present in the wet season enabling better identification of species. Each site was visited for a single day and a night and sampled opportunistically. During the first wet 
season trip, a team of two botanists, a land snail specialist, a herpetologist and four Traditional Owners was based on the mainland (Mungalalu Truscott Airbase) and sites were accessed using two Bell B206 Jet Ranger helicopters. Flora sampling, where each quadrat was revisited, was conducted during the day and the sampling of land snails and frogs during the late afternoon and evening. For the remaining two wet season surveys, the team was based on a charter vessel (MV Kimberley Escape in 2009 and MV Odyssey in 2010). Sites close to the coast were accessed via a tender from the larger vessel, while inland sites were accessed by helicopter (which teamed up with the vessel). Most personnel returned to the vessel following sampling each day/evening, although some camped overnight on the island and returned to the vessel the following morning. The duration of these trips was around 18 days.

\section{TRADITIONAL OWNER PARTICIPATION}

Wanjina-Wunggurr Uunguu, Wanjina-Wunggurr Dambimangari and Bardi-Jawi native title determinations, and Balanggarra and Mayala native title claims together cover all the islands surveyed. As such, collaboration with native title holders and claimants (Traditional Owners) was vital. The terms of this collaboration were set out in a Cooperative Research Agreement between the DEC project team and the KLC, the body with statutory responsibility for representing the interests of Traditional Owners in the Kimberley. Facilitated by the KLC, and prior to each field trip, information about the survey, such as employment opportunities, benefits of the project to the community and where and what will be sampled, was presented at community meetings. Once approval for the survey was obtained and the survey sites agreed on, willing participants (as paid consultants) from the relevant community were identified and allocated to survey teams (Appendix 1). The participants assisted in all aspects of the field work, and provided important guidance about culturally appropriate locations for camp sites and sampling activities.

\section{ACKNOWLEDGEMENTS}

We thank the participating Traditional Owners, Aboriginal rangers and base camp volunteers who contributed to the successful implementation of the field work. Thanks to all colleagues involved, especially base camp staff (see Appendix 1). We thank the crew of MV Kimberley Escape, MV Odyssey and pilots from Heliwork and Broome Helicopters for transporting teams safely. Andrew Burbidge kindly assisted with the initial helicopter logistics and Tony Start coordinated the first field survey. We are grateful to the DEC regional staff from the Kununurra and Broome Districts for their support during the project. DEC staff based at the Mitchell River National Park provided valuable logistical support. The project was possible through a research agreement with the KLC for the Balanggarra, Bardi-Jawi, Wanjina-Wunggurr Dambimangari, Mayala and Wanjina-Wunggurr Uunguu native title groups. Keith Claymore, Tricia Handasyde, Greg Keighery, David Pearson and two anonymous reviewers provided valuable comments on the manuscript. Funding was provided by the Natural Heritage Trust and DEC.

\section{REFERENCES}

ANZECC (2001). Biodiversity conservation research: Australia's priorities. Australian and New Zealand Environment and Conservation Council and Biological Diversity Advisory Committee, Environment Australia: Canberra. http://www. environment.gov.au/biodiversity/publications / research-priorities/index.html

Burbidge, A.A. and Manley, B.F.J. (2002). Mammal extinctions on Australian islands: causes and conservation implications. Journal of Biogeography 29: 465-475.

Burbidge, A.A. and McKenzie, N.L. (1978). The islands of the north-west Kimberley: Western Australia. Wildlife Research Bulletin Western Australia No. 7. Department of Fisheries and Wildlife: Perth.

Burbidge, A.A., McKenzie, N.L., Brennan, K.E.C., Woinarski, J.C.Z., Dickman, C.R., Baynes, A., Gordon, G., Menkhorst, P.W. and Robinson, A.C. (2008). Conservation status and biogeography of Australia's terrestrial mammals. Australian Journal of Zoology 56: 411-422.

Burbidge, A.A, McKenzie, N.L. and Kenneally, K. (1991). Nature conservation reserves in the Kimberley, Western Australia. Department of Conservation and Land Management: Perth.

Carwardine, J., O'Connor, T., Legge, S., Mackey, B., Possingham, H. and Martin, T. (2011). Priority threat management to protect Kimberley wildlife. CSIRO Ecosystem Sciences: Brisbane. http://www.csiro.au/ files/files/pzk8.pdf

CCWA (2010). Status performance assessment: biodiversity conservation on Western Australian islands. Phase II - Kimberley islands. Unpublished report to the Conservation Commission of Western Australia. The Government of Western Australia: Perth.

DEC (2009). A synthesis of scientific knowledge to support conservation management in the Kimberley region of Western Australia. Department of Environment and Conservation: Perth. http://www.dec.wa.gov.au/ component/option,com_docman/task,doc_details / gid,3407/Itemid,2219/

Fitzsimmons, J., Legge, S., Traill, B. and Woinarski, J. (2010). Into oblivion? The disappearing native mammals of northern Australia. The Nature Conservancy: Melbourne. http://www.feral.org.au/wp-content/ uploads/2010/09/into_oblivion.pdf

How, R., Schmitt, L., Teale, R. and Cowan, M. (2006). Appraising vertebrate diversity of Bonaparte Islands, 
Kimberley, Western Australia. Western Australian Naturalist 25: 92-110.

How, R.A., Spencer, P.B.S. and Schmitt, L.H. (2009). Island populations have high conservation value for northern Australia's top marsupial predator ahead of a threatening process. Journal of Zoology 278: 206-217.

Keighery, G., Gibson, N., Kenneally, K. and Mitchell, A. (1995). Biological inventory of Koolan Island, Western Australia 1. Flora and vegetation. Records of the Western Australian Museum 17: 237-248.

Laurance, W.F., Dell, B., Turton, S.M., Lawes, M.J., Hutley, L.B., McCallum, H., Dale, P., Bird, M., Hardy, G., Prideaux, G, Gawne, B., McMahon, C.R., Yu, R, Hero J-M., Schwarzkopf, L., Krockenberger, A., Douglas, M., Silvester, E, Mahony, M., Vella, K., Saikia, U., Wahren, C-H, Xu, Z., Smith, B. and Cocklin, C. (2011). The 10 Australian ecosystems most vulnerable to tipping points. Biological Conservation 144: 1472-1480.

Legge, S., Kennedy, M., Lloyd, R., Murphy, S. and Fisher, A. (2011). Rapid recovery of mammal fauna in the central Kimberley, northern Australia, following the removal of introduced herbivores. Austral Ecology 36: 791-799.

Losos, J.B. and Ricklefs, R.E. (2010). The theory of island biogeography revisited. Princeton University Press: Princeton, U.S.A.

Lydeard, C., Cowie, R.H., Ponder, W.F., Bogan, A.E., Bouchet, P., Clark, S.A., Cummings, K.S., Freat, T.J., Gargominy, O., Hershler, R., Perez, B.R., Seddon, M., Strong, E.E. and Thompson, F.D. (2004). The global decline of nonmarine molluscs. Bioscience 54: 321-330.

May, J.E. and McKenzie, N.L. (eds) (2002). A biodiversity audit of Western Australia's biogeographical subregions in 2002. Department of Conservation and Land Management: Perth.

McKenzie, N.L., Burbidge, A.A., Baynes, A., Brereton, R., Dickman, C.R., Gibson, L.A., Gordon, G., Menkhorst, R.W., Robinson, A.C., Williams, M.R. and Woinarski, J.C.Z. (2007). Analysis of factors implicated in the recent decline of Australia's mammalian fauna. Journal of Biogeography 34: 597-611.

McKenzie, N.L., Johnston, R.B. and Kendrick, P.G. (eds) (1991). Kimberley rainforests of Australia. Surrey Beatty and Sons: Chipping Norton, Australia.

McKenzie, N.L., Fontanin, L., Lindus, N.V. and Williams, N.R. (1995). Biological inventory of Koolan Island, Western Australia. 2. Zoological notes. Records of the Western Australian Museum 17: 249-266.

Nias, R.C., Burbidge, A.A., Ball, D. and Pressey, R.L. (2010). Island arks: the need for an Australian national island biosecurity initiative. Ecological Management and Restoration 11: 166-167.
Nix, H. and Kalma, J. (1972). Climate as a dominant control in the biogeography of northern Australia and New Guinea (pp 61-91). In: Walker, D. (ed.), Bridge and barrier: the natural and cultural history of Torres Strait. Research School of Pacific Studies Publication E6/3. Australian National University Press: Canberra.

Pearson, D., Greenlees, M., Ward-Fear, G, and Shine, R. (2009). Predicting the ecological impact of Cane Toads (Bufo marinus) on threatened camaenid land snails in north-western Australia. 36: 533-540.

Russell-Smith, J., McKenzie, N.L. and Woinarski, J.C.Z. (1992). Conserving vulnerable habitat in northwestern Australia: the rainforest archipelago (pp. 63-68). In: Moffatt, I. and Webb, A. (eds.), Conservation and development issues in north Australia. Australian National University, North Australia Research Unit workshop, September 1991: Darwin.

Shine, R. (2010). The ecological impact of invasive Cane Toads (Bufo marinus) in Australia. The Quarterly Review of Biology 85: 253-291.

Solem, A. (1991). Land snails of Kimberley rainforest patches and biogeography of all Kimberley land snails (pp 145-245). In: McKenzie, N.L., Johnson, R.B. and Kendrick, P.G. (eds.), Kimberley rainforests of Australia. Surrey Beatty and Sons: Chipping Norton, Australia.

Solem, A. and McKenzie, N.L. (1991). The composition of land snail assemblages in Kimberley rainforests (pp 247-263). In: McKenzie, N.L., Johnson, R.B. and Kendrick, P.G. (eds.), Kimberley rainforests of Australia. Surrey Beatty and Sons: Chipping Norton, Australia.

Start, A.N., Burbidge, A.A., McKenzie, N.L. and Palmer, C. (2007). The status of mammals in the north Kimberley, Western Australia. Australian Mammalogy 29: 1-16.

Woinarski, J.C.Z., Armstrong, M., Brennan, K., Fisher, A., Griffiths, A.D., Hill, B., Milne, D.J., Palmer, C., Ward, S., Watson, M., Winderlich, S. and Young, S. (2010). Monitoring indicates rapid and severe decline of native small mammals in Kakadu National Park, northern Australia. Wildlife Research 37: 116-26.

Woinarski, J.C.Z., Legge, S., Fitzsimmons, J.A., Traill, B.J., Burbidge, A.A., Fisher, A., Firth, R.S.C., Gordon, I.J., Griffiths, A.D., Johnson, C., McKenzie, N.L., Palmer, C., Radford, I., Rankmore, B., Ritchie, E., Ward, S. and Ziembicki, M. (2011). The disappearing mammal fauna of northern Australia: context, cause and response. Conservation Letters 4: 192-201.

MANUSCRIPT RECEIVED AUGUST 2011; ACCEPTED OCTOBER 2011. 
APPENDIX 1 Personnel involved in the field sampling for each survey.

\begin{tabular}{ll} 
Survey date & Personnel \\
\hline & Vertebrates: Andrew Burbidge, Mark Cowan, Lesley Gibson, Russell Palmer, \\
& David Pearson and Tony Start \\
& Flora: Tricia Handasyde, Greg Keighery and Mike Lyons \\
Land snails: Vince Kessner, Roy Teale and Michael Shea \\
Traditional Owners (TOs): Charlie Bundamurra, Derek Charles, \\
Dorothy Djanghara, Sylvia Djanghara, Warren Djanghara, Jeremy Kowan, \\
Damien Lawford and Neil Waina \\
Base camp: Jim Rolfe, Phil Fuller and T. Limantachai
\end{tabular}

Vertebrates: Paul Doughty

February 2008

Flora: Greg Keighery and Mike Lyons

Land snails: Vince Kessner

TOs: Jason Adams, Alphonse Fredericks, Jeremy Kowan and Shane Undalgamen

May-June 2008

Vertebrates: Mark Cowan, Lesley Gibson, Peter Kendrick, Norm McKenzie, Russell Palmer and David Pearson

Flora: Tricia Handasyde, Mike Lyons and Tony Start

Land snails: Vince Kessner, Roy Teale and Michael Shea

TOs: Victor Barunga, John Jangoot, Jacqueline Mungulu, Deidre Mungulu, Maitland Ngerdu, Duane Ngerdu, Edmund Lee Ngerdu Jnr, Janine Numendumah, Elvina Oobagooma, Brett Oobagooma, Wayne Oobagooma, Sonnette Ozies, Thorvald Ozies, Pedro Palacios, Craig Rastus, Alfred Umbagai, Anita Umbagai and Kirk Woolagoodja

Base camp: Wes Caton, T. Limantachai, Bill Muir and Jim Rolfe

Vertebrates: Wes Caton, Lesley Gibson and Russell Palmer

August 2009

Flora: Tricia Handasyde

(Adolphus Island)

Land snails: Vince Kessner

TOs: Lionel Mitchell and Kevin Morgan

Vertebrates: Paul Doughty

January 2009

Flora: Tricia Handasyde

(Adolphus Island)

Land snails: Vince Kessner

TOs: Lionel Mitchell and Kevin Morgan

Vertebrates: Paul Doughty, Lesley Gibson and Russell Palmer

February 2009

Flora: Tricia Handasyde and Greg Keighery

Land snails: Vince Kessner

TOs: Tristan Burgu and Alfred Umbagai 
Vertebrates: Mark Cowan, Lesley Gibson, Norm McKenzie, Russell Palmer, David Pearson and Duncan Sutherland

Flora: Tricia Handasyde, Greg Keighery and Mike Lyons

Land snails: Vince Kessner, Frank Kohler and Sean Stankowski

May-June 2009

TOs: Jordan Barunga, Kalvin Hudson, Jahni Issac, Sandy Isaac, Herman Ishmail, John Jangoot, Terry McCarthy, Aaron Mungulu, Edmund Lee Ngerdu Jnr, Wayne Oobagooma, Sonnette Ozies, Thorvald Ozies, Pedro Palacios, Craig Rastus, Nathan Sampi, Aubrey Tigan, Mitchell Tigan, Alfred Umbagai and Anita Umbagai

Base camp: Wes Caton and Jim Rolfe

Vertebrates: Lesley Gibson, Russell Palmer and David Pearson

February 2010

Flora: Tricia Handasyde and Mike Lyons

Land snails: Vince Kessner and Roy Teale

TOs: Lionel Cox, Ian Heally, Craig Isaac, Herman Ishmail, Terry McCarthy, Craig Rastus and Trevor Sampi

June 2010

(Wargul Wargul and Mary Islands)
Vertebrates: Wes Caton, Lesley Gibson and Russell Palmer

Flora: Greg Keighery

Land snails: Vince Kessner

TOs: Sylvester Mangolamara, Bruce Oxtoby and Desmond Williams 